\title{
Making a strategy for Europe
}

\section{The European Commission's heart may be in the right place in the support of science and technology, but it must learn patience. Europe will be there a century from now.}

The European Community is going through a strange and unrecognized metamorphosis. President Ronald Reagan has come and gone, leaving behind him a trail of disappointment. What worries Europeans most is not that he was less than wellinformed about their affairs but that so little happened or got done. The Falklands war has been settled, after a fashion, reminding Europeans that in the last resort blood, which means financial common interest, is thicker than water. However reluctantly, the members of the Community found that they had no choice but to go along with the unexpected British assertion of national purpose (and Irish diffidence on this point so to speak is the exception that proves the rule). Meanwhile, the whole of Europe is perplexed that there should be little it can do about the mounting crisis in the Middle East. There is almost nothing that can be done to avert the slow rosion of Chancellor Helmut Schmidt's government in Bonn. This and the concatenation of dismal happenings has, however, had a paradoxical effect Europeans seem to have been convinced that they are in the same boat, and that they had better make the best of it. The constructive performance of the government of France at the Versailles summit, however eccentric, has been heartening for everybody on the east of the Atlantic. This, strange as it may seem, is the spirit in which the meeting of the council of science ministers of the Community this week should be judged.

The objective of the meeting is to make a further step towards a science policy for the European Community. It tends to be forgotten that the Community has had a science policy since before its own creation - a policy called Euratom. It is, however, well within living memory that whenever the Community has since tried to hammer out some concerted plan of action on its support of science and technology, the result has been conspicuously inconspicuous. Plans for coordinated programmes of research and development in computers, or telecommunications, have regularly foundered or have been stillborn. The explanation is familiar but unremembered - national governments will not commit national funds to a common programme of research and development if they fear that their gain will be proportionately less than their financial contribution. To ensure that such an outcome will not arise, they insist that whatever cooperative programmes there may be should be tightly controlled by representatives of the Community's member states, which is a recipe for making sure that the programmes will be second-rate. Will this week's meeting have a better chance of succeeding?

This meeting (see page 619) is at least well prepared. The council of ministers of science has been deluged with paper. There is also a hefty background document to direct attention to the directions in which, on a kind of statistical-historical view of events, the wind is blowing (see Nature 17 June, p.528). The Commission's new proposals show that it has learned something from the

\section{US contributions}

Authors in the United States and Canada are reminded tnat they should send their manuscripts either direct to London or to the Washington office at 991 National Press Building, Washington DC20045; manuscripts should not be sent to Nature's New York office. disappointments of the past quarter of a century; the intention now is that there should be a political decision about the fields in which Community funds might be spent in the interests of the Community as a whole, a kind of political assessment of more detailed plans for spending money in the selected areas and then, finally, the making of research grants by specialist committees. The procedure proposed has the obvious advantage of putting a distance between the politicians who provide the funds and those who ultimately decide how they should be spent. The distance, however, is unlikely to be great. The committees that spend the money will be creatures of the member governments, and their members not so independent that they will be able to snap their fingers at those who nominate them. The best to hope for is that the regime now proposed will repeat past mistakes less glaringly.

Before it is too late, there is another model that European governments should consider - the agreement signed last week between the principal research councils of the United Kingdom and the Netherlands (see page 616). Even this marriage of convenience has arisen more or less by accident, partly because the British and the Dutch share common scientific interests and frustrations and partly because they get on well with each other in a wider context. Moreover, the deal now struck by the research councils falls far short of being a full marriage - there is no suggestion that British funds should for the time being be used to support research carried out in Dutch laboratories by nationals of the Netherlands. Yet the benefits of even this arrangement are classically simple. In at least some respects, the community of ideas will be enlarged.

The lesson for the European Community in this tale is that it takes time - and decades, not years - to bring about a tangible sense of collaboration between naturally competitive creative people, and that the collaboration works well only when the people who decide what should be done are the people who will then do the work. The model is persuasive, but by no stretch of the imagination quick enough for the European Commission's purpose. How, the Commission will be asking, can the "technology gap" then be bridged?

In reality, there must be some middle road. For political reasons, the Commission seeks to invest in research, necessarily applied research, that will both strengthen the sense of community and yield some practical benefit in the short run. Notoriously, what it wants can be accomplished only in the sphere in which commercial companies are strong and even dominant. It would be better advised to back away from the goal of immediate benefit, seeking instead to improve the cohesion of the research community. The imaginative use of Community funds for helping people from member states to move more freely within the Community would be a start, especially if the scope of such a scheme could be enlarged beyond the fields now cultivated by the European academies and by the European Science Foundation. Modest grant-making through independent bodies of trustee-like dignatories would help still further if the grants found their way to those who in the judgement of their peers deserved them. Such painstaking work cannot, of course, be courted on to close the technology gap by some arbitrarily chosen target date, but no deliberate policy will do that (although luck might). But if Europe is here to stay, as the events of the past few weeks appear to attest, it will still be here a century or so from now. 